Katarína Kolbiarz Chmelinová

\title{
UNIVERSITY ART HISTORY IN SLOVAKIA AFTER WWII AND ITS SOVIETIZATION IN THE 1950S*
}

World War II dramatically altered the face of Europe, and university education in Slovakia, again part of Czechoslovakia, did not escape its influence. Many decades have passed, but our knowledge of these issues still contains gaps. This is due to the fact that the nature of the material studied resembles a murky quagmire. The text that follows is the very first attempt to present in greater detail the extent and character of changes in university art history instruction in the socialist era of the Czechoslovak Republic, i.e. up to 1960. Like it or not, we are its heirs, and the roots of the present system of university teaching of this discipline stretch all the way back to that time. This contribution represents an in-depth probe into the postwar efforts to build a new university foundation and system of art history instruction in Slovakia within the Czechoslovak Republic and its sovietization. It focuses on the extent and character of changes reflected in the composition of programs of study, the organization of extra-curricular activities and the politically unstable composition of the art history faculty members. Its core is particularly constituted by transformations in pedagogical processes from the early $1950 \mathrm{~s}$ in the period of the communist regime consolidating its hold. It is also based on the study and comparison of hitherto-unprocessed sources from various universities and state and private archives, and their classification in terms of known historical facts. The issues are primarily considered as an expression of an independent social and cultural system and not from the aspect of the negatively simplifying concepts of totalitarianism. ${ }^{1}$ The aim of this text is to broaden the factual basis and existing overview of knowledge of art history

* I would like to express my gratitude to Alexandra Kusá (Slovak National Gallery Bratislava), Eva Kowalska, Marína Závacká and Adam Hudek (Slovak Academy of Sciences in Bratislava) for their kind consultations at the beginning of my research.

${ }^{1}$ See e.g. S. Kotkin, Magnetic Mountain: Stalinism as a Civilization, Berkeley-Los Angeles-London 1997. 
in Slovakia in the form of a case study. Opening up a new subject also represents a contribution to the growing discussion on the postwar sovietization of Czechoslovak cultural policy in its Slovak variant. ${ }^{2}$

After WWII, art history as a university field of study was available in Slovakia only at the Slovak University in Bratislava, which was its provisional name during the time of the First Slovak Republic. The university reverted to its original name, Comenius University, in 1954. ${ }^{3}$ František Žákavec established the Seminar of Art History ${ }^{4}$ at the university in 1923 and was his head until his death in $1937 . .^{5}$ In contrast to the Czech Republic, where on November 17, 1939 all Czech universities were closed and only four German universities remained active, university education in Slovakia was not interrupted. ${ }^{6}$ Nevertheless, the Slovak University in Bratislava was forced to follow the political-ideological dictates of German culture policy on education, as well as the nationalist tendencies in society at the time. ${ }^{7}$ (ill. 1)

On the eve of WWII, the Seminar of Art History struggled with the same staffing issues which had existed from the very beginning. Solutions were nothing more than provisional throughout the war, and the administrative management of the Seminar was repeatedly replaced. First, it was Jan Eisner,

2 An extensive publication concerning art and Stalinist cultural practice in Slovakia was published recently: A. Kusá, Prerušená pieseň. Výtvarné umenie v časoch stalinskej kultúrnej praxe 1948-1956, Bratislava 2019. Ad transformations in university study in the Stalinist era see S. Gabzdilová, Ako sme študovali v totalite. Vysokoškolské vzdelávanie na Slovensku pod ideologickým diktátom Komunistickej strany Československa 1948-1953, Prešov 2018.

3 95 + Dejiny umenia na Univerzite Komenského v Bratislave, eds. K. Kolbiarz Chmelinová, K. Beňová, Bratislava 2018, p. 63, 66.

4 Seminár dejín umenia /Seminar of Art History was a coeval title for the individual part of the Faculty structure teaching art history field of study before conversion to a department.

5 95+ Dejiny umenia..., p. 63. On F. Žákavec's life and art history work see: I. Ciulisová, Dejepis umenia na Slovensku. Vybrané kapitoly, Bratislava 2011, pp. 17-19.

${ }^{6}$ A. Hudek, "Sovietizácia pracovísk historickej vedy na Univerzite Komenského v 50. rokoch," in: 95 rokov Filozofickej fakulty UK, PohPad do dejín inštitúcie a jej akademickej obce, eds. M. Slobodník, M. Glossová, Bratislava 2017, p. 324; J. Connelly, Captive University: The Sovietization of East German, Czech, and Polish Higher Education, 1945-1956, The University of North Carolina Press 2000, pp. 16-17, 118.

7 B. Koklesová, "Seminár dejín umenia v rokoch 1939-1945," in: 95 rokov Filozofickej fakulty..., pp. 306-322. The authoress has endeavored to delineate the means by which the German ideology was implemented in universities and to characterize the transformation that the education of humanities and social sciences underwent in the official political order. 


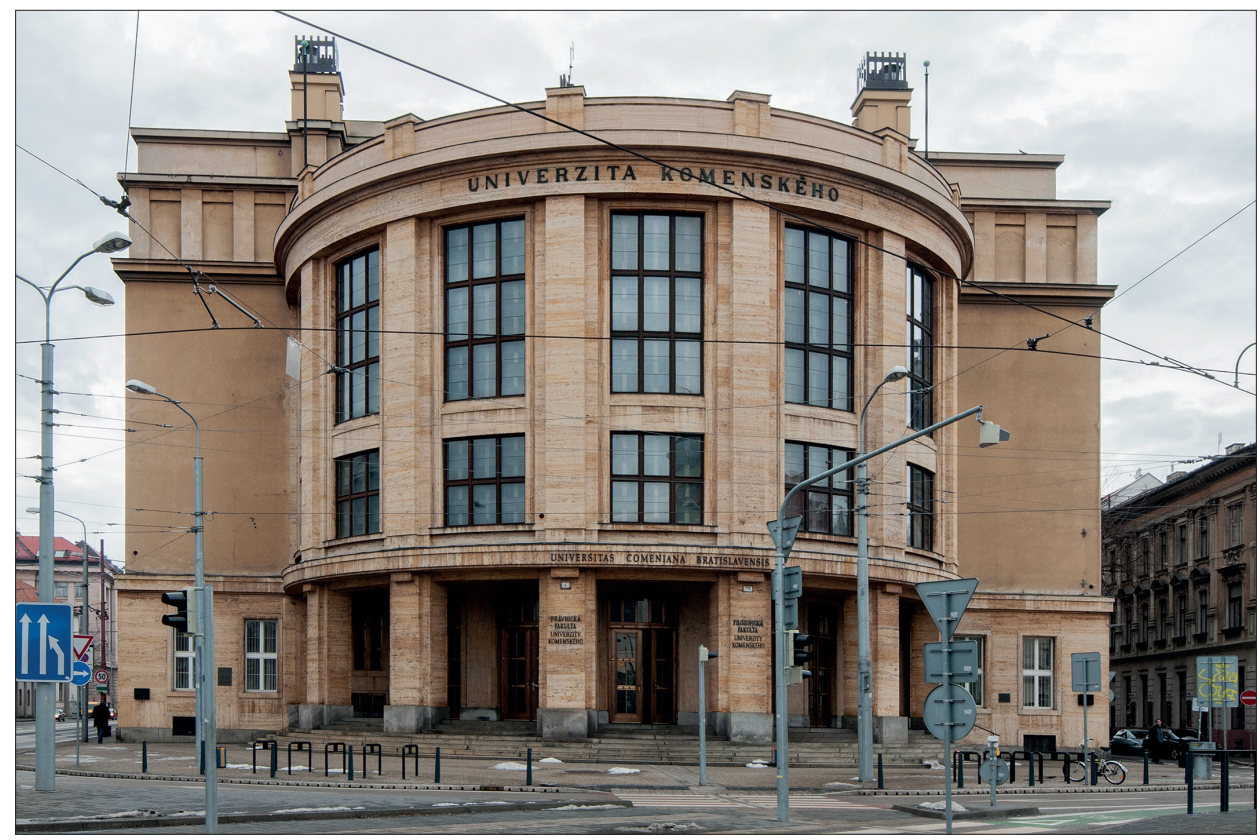

1. Comenius University in Bratislava, Faculty of Arts and Faculty of Law, seat of Art History Subdepartament in the 1950s. Photo: Olja Triaška Stefanovic

a professor of Prehistoric Archeology. He was replaced in the 1940/1941 academic year by Branislav Varsík, a professor of General History, who was succeeded by Andrej Mráz, a professor of the History of Slovak Literature (from 1942/1943). However, the executive duties fell on the shoulders of Eugen Dostál, an art history professor from the University of Brno, and a student of the famous Max Dvořák. ${ }^{8}$ When he suddenly died in 1943, it was clear that he, like his predecessors, had not managed to prepare a much-needed successor and thus he did not leave a deeper mark on art history instruction in Slovakia. Although the Czech art historian Václav Mencl was granted an associate professorship at Comenius University in 1938, he and his wife Dobroslava, an expert in Slovak architecture, were forced to leave Slovakia because

${ }^{8}$ J. Bakoš, "Príbeh zakliatej vednej disciplíny. Seminár dejín umenia na Bratislavskej univerzite", in: Pocta Václavovi Menclovi. Zborník štúdií k otázkam interpretácie stredoeurópskeho umenia, Bratislava 2000, p. 11. The article is a key text on the history of the Department of Art History at the Faculty of Arts at the Comenius University in Bratislava. For the list of lectures on art history by Prof. Dostál in Bratislava, see the academic year 1941/1942 in: 95+ Dejiny umenia..., p. 95. 
of the war. ${ }^{9}$ Jozef Cincík, a Ph.D graduate from the University of Bratislava, did not participate in its educational mission. Although he was appointed professor of Art History by President Jozef Tiso in 1945, he emigrated the very same year. ${ }^{10}$ Apart from the aforementioned educators, students interested in art history could meet with young Alžbeta Güntherová Mayerová. As a former student of the Seminar, she served as a part-time museum lecturer along with other jobs. Her work at the university was apparently related to Prof. Žákavec's absence due to his illness and his eventual departure shortly before the war. She was appointed Lecturer of Museology at the Faculty of Arts of the Slovak University in December 1940. Subsequently, she had to undergo a political examination proving her non-Jewish origins in order to retain the position until 1952. ${ }^{11}$ (ill. 2) Although she lectured on only two courses a year related to museology and monument preservation practice, they were mostly the only art history-related courses available after the death of E. Dostal. ${ }^{12}$ The Seminar of Art History at the Slovak University was continuously offered during the war, but only to a limited extent. According to the course schedule from the 1944/1945 academic year, the only two courses related to art history were taught by Alžbeta Güntherová Mayerová: Monument Pres-

9 Ciulisová, Dejepis umenia..., p. 28. He was expected to start in the winter term 1938/39, nevertheless in 1938 he returned to Czechia. For more information, see: Pocta Václavovi Menclovi. Zborník štúdií k otázkam interpretácie stredoeurópskeho umenia, eds. D. Bořutová, Š. Oriško, Bratislava 2000. After the war he temporarily returned to the university in Bratislava. 95+ Dejiny umenia..., pp. 67-68, 96.

10 J. Okál', Dr. Jozef Cincík. Pútnik dvoch svetov, Ontario 1980.

${ }^{11}$ K. Kolbiarz Chmelinová, "The pedagogical activity of Alžbeta Güntherová-Mayerová (1905-1973) at the Comenius University." The manuscript of the lecture that revised the hitherto knowledge was presented at the Faculty of Arts at the Comenius University on March 20 th, 2019 and will be published in Ars 1/2020. For an earlier comprehensive article on Güntherová-Mayerová, see: Stretnutie so životom a dielom Alžbety Güntherovej-Mayerovej (1905-1973). Zborník príspevkov z kolokvia Umelecko historickej spoločnosti Slovenska 27.11.2003, Bratislava 2003.

12 E. Šefčáková, "Alžbeta Güntherová-Mayerová - život a dielo," in: Stretnutie so životom..., p. 25, footnote 41. Progress reports indicate that she lectured in Conservation and Installation Works in Museums and Determining Genuinity of Art Works in 1942/43, Sculpture Techniques and Heritage Preservation in 1944, and Basic Terminology of Collecting and Museology and Development of Styles in Visual Art in 1946. A manuscript of the lecture on sculpture and its techniques from 1945 is in the Archív výtvarného umenia Slovenskej národnej galérie v Bratislave / Archive of Visual Art of the Slovak National Gallery in Bratislava (AFA SNG BA), Osobný fond A. Güntherová-Mayerová, sign. 10 E 342, L. Peterajová, "Pôsobenie Alžbety Güntherovej-Mayerovej na Vysokej škole výtvarných umení," in: Stretnutie so životom..., p. 100. 
ervation and Techniques in Sculpture and Monument Preservation with field trips. ${ }^{13}$ The Seminar suffered from a severe lack of staff, which was only alleviated by temporary solutions. Unfortunately, the fate of art history in Slovakia in the interwar and war periods was mainly about the efforts of a few enthusiastic intellectuals rather than ideas and doctrines. ${ }^{14}$

There were no dramatic changes immediately following the war. Professor Andrej Mráz, a literary researcher of repute, was still officially the head of the Seminar of Art History after 1945. ${ }^{15}$ Apart from Alžbeta Güntherová Mayerová - still an associate lecturer - art history in 1946 and 1947 was covered by Valér Aurel Zavarský,

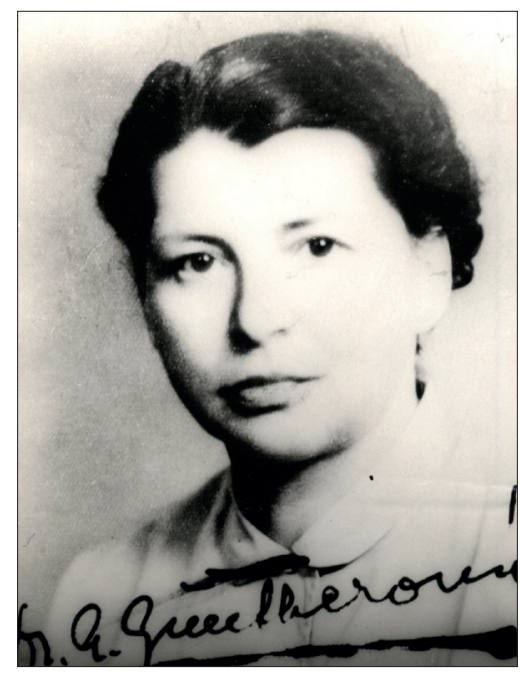

2. Alžbeta Güntherová Mayerová. Photo: ADAH FA CU BA a Jesuit priest. ${ }^{16}$ The first three years after the war were tranquil, as the organizational structure of the university management and the system of the pedagogical work essentially remained unaltered. Even the post-war political screening processes at the university had only a moderate impact, as the faculty representatives from the war period could not be accused of direct Fascist collaboration due to their attitude. ${ }^{17}$ In general, unlike in East Germany, efforts to restore and fill the academic positions in former Czechoslovakia, as well as in Poland was successful. ${ }^{18}$ The Commission of the Slovak National Council for Education and National Edification, established in 1944, was then the central managing body of the edu-

${ }^{13}$ Registratúrne stredisko Filozofickej fakulty Univerzity Komenského v Bratislave / Registrar office of the Faculty of Arts Comenius University in Bratislava (RO FA CU BA), Slovenská univerzita v Bratislave, Soznam osôb, ústavov a štátnych skúšobných komisií podl'a stavu na začiatku študijného roku 1944/45 a Soznam prednášok, ktoré budú v zimnom semestri študijného roku 1944/45, p. 42 and 146. Lectures lasted one hour and took place on Friday afternoons at the Seminar of Archeology at 12 Šafárikovo Square in Bratislava.

${ }^{14}$ Ciulisová, Dejepis umenia..., p. 46.

${ }^{15}$ Bakoš, "Príbeh zakliatej vednej disciplíny," p. 11; 95+ Dejiny umenia..., pp. 67-68.

16 J. Bakoš, Situácia dejepisu umenia na Slovensku, Bratislava 1984, pp. 180-181. More on Zavarský see: Život a dielo P. Valéra Aurela Zavarského S): konferencia pri príležitosti nedožitých stých narodenín, Bratislava 23. septembra 2005, eds. L'. Csontos, A. Piatrová, Trnava 2005.

17 Hudek, "Sovietizácia pracovísk...," p. 342; Gabzdilová, Ako sme študovali v totalite, pp. 19-20, 63, 76-77, 81.

18 Connelly, Captive University..., p. 4. 
cational system in Slovakia. According to the Košice Government Program, it was to be an equal partner with the Ministry of Education and Edification in Prague, but from 1946 it was subordinated to the Ministry. ${ }^{19}$

Nevertheless, undoubtedly the most momentous event was the Victorious February of 1948, resulting in the Communist's seizure of power in Czechoslovakia, the transformation to totalitarian rule and the nation's official joining of the Soviet Bloc. ${ }^{20}$ At the beginning of 1948, Czechoslovakia was the last country within the Soviet sphere of influence that was not under the decisive dominance of Communist power, but the February Communist coup d'état changed all that. Its impact affected the entire society and left a significant mark on art history at the University of Bratislava. ${ }^{21}$ The Communist leaders appointed their sympathizers to positions regardless of their age or experience. In 1948, Prof. Mráz, who provisionally led the Seminar of Art History, was replaced by the 32-year-old Jaroslav Honza-Dubnický, a structuralist, and a disciple of Eugen Dostál and Jan Mukařovský. ${ }^{22}$ Other educators active in the Seminar were Vladimír Wagner, Václav Mencl (ill. 3), briefly returning on a part-time basis, and Alžbeta Güntherová Mayerová as a lecturer. ${ }^{23}$ The extent of art history lectures at the university grew considerably. ${ }^{24}$ Due to political interventions, however, the hope of meaningful progress with the abovementioned pedagogical teams in the field of art history rapidly faded. In 1949, Assoc. Prof. Dubnický repudiated his pre-war work in art history in an expression of self-criticism inspired by the results of the $9^{\text {th }}$ Congress of the Communist Party. On Party orders, he left the Seminar of Art History. In 1950, he became a dean of the Faculty of Arts and ceased his activity in art history. Nevertheless, as the Dean and Head of the Department of General History and Archeology, he, along with Miloš Gosiorovský, another new 'ideologically mature' faculty member, became two of the most significant representatives of Marxist historical science of the subsequent period. ${ }^{25}$

19 Gabzdilová, Ako sme študovali v totalite, pp. 8-15.

${ }^{20}$ Compare with Connelly, Captive University..., p. 30; P. Hübner, Nauka polska po II wojnie światowej. Idee i instytucje, Warszawa 1987, pp. 12-22.

21 Bakoš, "Príbeh zakliatej vednej disciplíny," p. 12.

${ }^{22}$ Ibidem, p. 12 referred to as a head of the Seminar of Art History, and in the coeval record only as a member. Compare 95+ Dejiny umenia..., pp. 65-66. More on Dubnický I. Ciulisová, Dejepis umenia..., pp. 60-61.

${ }^{23}$ Illustrative syllabi in: 95+ Dejiny umenia..., p. 96.

${ }^{24}$ Ibidem.

${ }^{25}$ J. Hudek, "Personálna politika na historických katedrách Univerzity Komenského," in: idem, Najpolitickejšia veda. Slovenská historiografia v rokoch 1948-1968, Bratislava 2010, pp. 106-107. 
After 1948, profound changes in the structure of university education, as well as in the pedagogical teams, were evident in all of the Eastern and Central European countries of the Soviet Bloc. ${ }^{26}$ The aim of these changes was to emulate as closely as possible the system of higher education of the Soviet Union with its subservience to the government apparatus. The Communist parties in these countries gained control over the management of schools and universities; they appointed rectors, introduced instruction in Marxism-Leninism and followed the Soviet model. Local differences, however, led to discrepancies in the implementation of the Soviet model and to divergent processes of self-Sovietization. In the same year, univer-

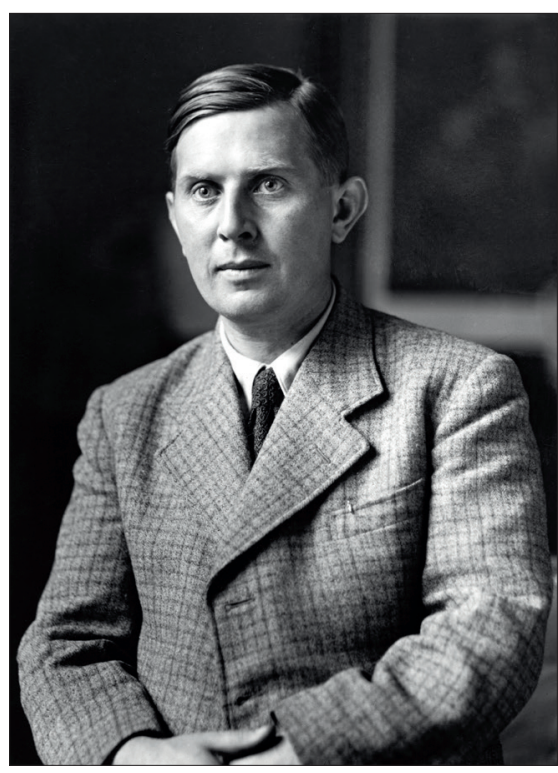

3. Václav Mencl. Photo: ADAH FA CU BA sities in Czechoslovakia saw a formation of studentocratia, where committees of students approved directly by the Czechoslovak Communist Party were formed to carry out the political screening of their classmates and teachers. ${ }^{27}$ Although Czechoslovakia was a unified country, the destructive impact of these purges in the period shortly after 1948 was not as harsh in Slovakia as in the Czech lands. For a brief moment, it seemed that we would be more inclined toward the Polish model rather than the Czech model. ${ }^{28}$ Generally, in Czechoslovakia, the interest of

26 Connelly, Captive University..., pp. 126-127.

${ }^{27}$ Hudek, "Personálna politika na historických katedrách...," p. 105. More in J. Jareš, "'Indiferentní - možnost převýchovy!' Cíle tzv. studijní prověrky na vysokých školách a jejich realizace," in: M. Černá, J. Cuhra akol., Prověrky a jejich místo v komunistickém vládnutí. Československo 1948-1989, Praha 2012, pp. 20-53. Political examinations through an executive committee governed by the Central Executive Committee of the National Front were stricter in relation to assistants working at universities than to professors, due to their closer contact with students. Hudek, "Sovietizácia pracovísk...," p. 344, footnote 14 .

${ }^{28}$ Hudek, "Sovietizácia pracovísk...," p. 342; P. Hübner, Polityka naukowa w Polsce w latach 1944-1953. Geneza systemu, vol. I, Wrocław-Warszawa-Kraków 1992, pp. 336449; Connelly, Captive University..., p. 4, 10. 
Party leaders in university education was minor. ${ }^{29}$ This was a result of their strong 'anti-intellectualist' attitudes and the absence of a clear, coordinated university policy at the top level of the Communist Party. In contrast to Poland, there was no attempt to adopt a new higher education act until 1950. ${ }^{30}$ Although transformations in the university system were prepared in 1948, adjustments at lower levels of study were a priority. ${ }^{31}$

In November 1950, Jaroslav Honza-Dubnický, the dean of the Faculty of Art, described the faculty as an ideological institution with the task of developing high-profile experts and strong supporters of Marxism-Leninism. ${ }^{32} \mathrm{Si}$ multaneously, the Czechoslovakia Act No. 58/1950 on Higher Education was passed. The following two years witnessed a radical (self)-Sovietization of the scientific - research base, which had an effect on the position and functioning of universities in Czechoslovakia. ${ }^{33}$ It occurred in a three-stage process. Firstly, the implementation of the new Higher Education Act enforced central governing through the authorities of the Communist Party of Czechoslovakia. The State Committee for Higher Education Institutions, which was established by the state, provided proposals to the minister for the management of universities, faculties and their newly constituted departments, as well as departments and scientific institutes themselves, and decisions concerning the competence and scope of activities of professors and associate professors, became the key element of the reform. Following the Soviet model, changes to the internal structure of faculties and new departments were also implemented at the beginning of the 1950/51 academic year. ${ }^{34}$ As a result, the Sem-

${ }^{29}$ Hudek, "Sovietizácia pracovísk...," p. 346.

30 Connelly, Captive University..., pp. 55-56, 62-63. After 1948, in Czechoslovakia limited reforms were designed to bring the university closer to the mode of production. They had not been properly implemented by 1950, when modes of production became a compulsory part of syllabi.

${ }^{31}$ Gabzdilová, Ako sme študovali v totalite, pp. 8-15, 19. As opposed to the Czech Republic, the overall changes in the school system in Slovakia were introduced with the aim of achieving a "unified school" since its nationalization in 1944 and 1945. This was followed in 1948 by a nationally applicable act on the basic arrangement of a unified school system. However, the changes were only related to lower levels of study. J. Pšenák, Pramene k dejinám Československého školstva (od. r. 1918-1973), Bratislava 1977, pp. 11-17, 57-91.

32 Archív Univerzity Komenského v Bratislave / Archive of the Comenius University in Bratislava (A CU BA), fond: Zápisnice zo zasadnutia Akademického senátu 1949-1950, Referát J. Dubnického 13.11.1950

${ }_{33}$ Collection of Laws of the Slovak Republic. Act No. 58/1958, https://www.slov-lex. sk/pravne-predpisy/SK/ZZ/1950/58/19660501 (15.5.2018); Gabzdilová, Ako sme študovali v totalite, pp. 27-30; Hudek, "Sovietizácia pracovísk...," p. 347.

$3495+$ Dejiny umenia..., p. 66. 
inar of Art History lost its independence. It remained under the broad field of study of Art Sciences and was subsequently assigned to the Department of Art Sciences with Prof. Bakoš as its head. ${ }^{35}$ The preparation of new plans and curriculums of study, as well as study and examination regulations, all approved by the Minister, also related to the changes. Based on the resolution of the Central Committee of the Communist Party of Czechoslovakia, the teaching of Marxism-Leninism became compulsory in 1951-1952. ${ }^{36} \mathrm{Sec}-$ ondly, following the Soviet model, there was an effort to restrain universities from science research and publishing; these activities would be carried out by the academies of sciences. Universities, and faculties of arts in particular, were expected to concentrate on pedagogical and political-educational tasks designed to create a Marxist intellectual elite. ${ }^{37}$ The third and crucial part of the Sovietization process was the new, Stalin-initiated round of purges aimed at eliminating enemies of the regime. ${ }^{38}$ In Slovakia, they took the form of the struggle against bourgeois nationalism, particularly against intellectuals, and in compliance with the instructions which arose from the aforementioned 9th Congress of the Czechoslovak Communist Party in 1950, they were directed not only against students but also lecturers, who were perceived as the weakest, Marxist-ignorant elements of the new university system. As part of the process, all of the employees of the Faculty of Arts of the Slovak University had to participate in humiliating expressions of self-criticism. This was done publicly (June 23th, 1950) and its goal was to expose deficiencies in the functioning of faculties in terms of Marxism and republic-building. Shortly afterwards, as a result of the conference of art historians and art theoreticians in Bechyně in 1951, Stalinist ideology was elevated to the level of the law on art history. ${ }^{39}$ Its conclusions were discussed in June of the same year at regular ideological meetings of the Sub-department of Art History at the University of Bratislava. ${ }^{40}$ Moreover, the evolving Stalinist regime after 1948 brought

${ }^{35}$ Ibidem. The published list of lectures includes an option to study art history in 1952 at the Department of General History, Archeology and Ethnology with Dubnický as principal. In the minutes from the meetings of departments, however, art history is recognizably a part of the Department of Art Sciences. Compare RO FA CU BA, Fond A II/1, A5 Zápisnice zo zasadnutí Katedry vied o umení 1951-1959.

${ }^{36}$ Gabzdilová, Ako sme študovali v totalite, pp. 116-19.

37 Hudek, "Sovietizácia pracovísk...," p. 348.

${ }^{38}$ Hudek, Najpolitickejšia veda..., p. 106.

39 I. Ciulisová, "Lesk a bieda slovenskej kunsthistórie II (Slovenský dejepis umenia 1948-1968)," in: eadem, Dejepis umenia na Slovensku, p. 61.

${ }^{40}$ RO FA CU BA, Fond A II/1, A5 Zápisnice zo zasadnutí Katedry vied o umení 19511959. Správa o činnosti subkatedry dejín výtvarného umenia za letný semester 1951. 
a significant change in the social standing of art historians, which was manifested in its degradation and in many cases manipulation. ${ }^{41}$

The Department of Art Sciences, like others, functioned and was regulated in accordance with pre-designed quarterly, and later semiannual plans. ${ }^{42}$ Minutes from sessions of the Department of Art Sciences, particularly the Sub-department of Art History, provide insight into the implementation of the new processes of (self)-Sovietization in the functioning of art history.43 The sessions, often lasting several hours, with agendas comprising issues related to staffing, management and education, typically commenced with a thematic, ideological - political discourse. Particular attention was paid to the analysis of the pedagogical activities of every member in the form of criticism and self-criticism; not even the heads of the departments and sub-departments were spared. As of January 1951, the aforementioned criticism and self-criticism of lectures was supposed to be a subject of meetings at the trade union level and only later at the department level. The same applied to the criticism of the plans of study. ${ }^{44}$ In the Sub-department of Art History at that time, this took on an informative and formal character, as illustrated by the self-criticism of Assoc. Prof. Wagner (ill. 4) from March 1951. ${ }^{45}$ He pointed out the lack of the Sub-department's technical and spatial facilities and his own struggle in search of the appropriate implementation of Marxism-Leninism in art history. The governing, controlling mechanism of the criticism of the lectures favorably reflects the concentrated interest in issues of didactics at the university (such as supervising the content of textbooks, required syllabuses, the functioning of the courses and their guides, discussions on plans of study or the sharing of experience from exams). The mechanism, which with time and increasing audiences, as well as discussions on its implementation at higher levels, e.g. the entire Department of Art Sciences, was transformed into a potential danger for a pedagogue. At the time of the implementation of this process, all of the educators of art history in Bratislava were employed elsewhere in or outside the city, which was one of the reasons for scheduling the sessions in the evenings. Students were recommended to also attend the lectures by Karol Veselý at the Academy of Fine Arts and Design. In coopera-

${ }^{41}$ Ibidem, pp. 62-63.

${ }^{42}$ RO FA CU BA, Fond A II/1, A5 Zápisnice zo zasadnutí Katedry vied o umení 19511959. Zápisnica zasadnutia z 26. januára 1951.

${ }^{43}$ RO FA CU BA, Fond A II/1, A5 Zápisnice zo zasadnutí Katedry vied o umení 1951-1959.

${ }_{44}$ Compare with RO FA CU BA, Fond A II/1, A5 Zápisnice zo zasadnutí Katedry vied o umení 1951-1959, Zápisnica z 26.1.1951.

45 RO FA CU BA, Fond A II/1, A5 Zápisnice zo zasadnutí Katedry vied o umení 19511959, Zápisnica zo 17. marca 1951. 
tion with Zväz slovenských výtvarných umelcov (the Alliance of Slovak Visual Artists) the students were given an opportunity to visit studios and thus get a feel for the contemporary art scene.

The minutes from the session of the entire Department of Art Sciences in May 1951 provide a useful source of information. ${ }^{46}$ At the beginning, Assoc. Prof. Wagner, the head of the Sub-department of Art History, commented on cosmopolitanism and bourgeois nationalism in art in connection with decadent tendencies. In accordance with contemporary cultural policy, he stated that overcoming these tendencies would be the only

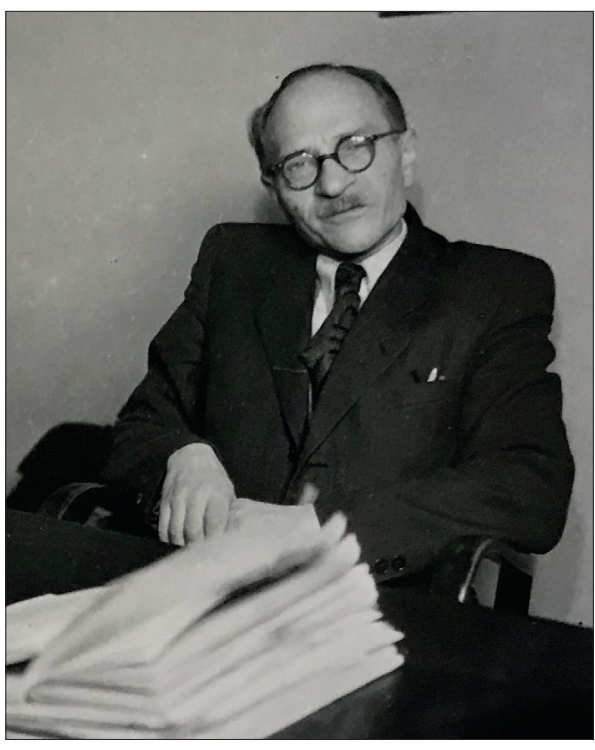

4. Vladimír Wagner. Photo: AFA SNG BA way to establish socialist realism. He criticized Slovak artists such as Ludovít Fulla († 1980) and Mikuláš Galanda $(\dagger 1938)$ as being infected by decadent art from the West. Quoting from the source: Galanda displays the quiet sadness of a bourgeois cosmopolite, Sokol's work (he left Slovakia in 1948 and never returned), which was interpreted as progressive, displays false revolutionary spirit, formalism, and a crude caricature of the working class... ${ }^{47}$ The discussion that followed was extensive and Prof. Mikuláš Bakoš, the head of the Department, praised Wagner's attitude toward the avant-garde. Moreover, the department agreed to elaborate on this subject in discussions at the level of individual study branches. Wagner introduced the subject by presenting slides of selected artworks shortly before the lecture at the long meeting of the Sub-department of Art History. ${ }^{48}$ Issues concerning the lack of staff and the need to develop new experts were also raised. ${ }^{49}$

46 RO FA CU BA, Fond A II/1, A5 Zápisnice zo zasadnutí Katedry vied o umení 19511959, Zápisnica zo 7. mája 1951.

47 Compare with the coeval attitude towards avant-garde in Kusá, Prerušená pieseň..., pp. 53-55, 116-122, 294-295, 383-384.

48 RO FA CU BA, Fond A II/1, A5 Zápisnice zo zasadnutí Katedry vied o umení 19511959, Zápisnica subkatedry zo 4. mája 1951. The session lasted from 19:30 to 23:30, and Dr. Dubnický and Dr. Váross were invited.

49 RO FA CU BA, Fond A II/1, A5 Zápisnice zo zasadnutí Katedry vied o umení 19511959, Zápisnica zo 7. mája 1951. 
This was particularly urgent at the Sub-department of Art History where the lectures by part-time lecturers Vojtěch Volavka and Jiří Kotalík were taking place non-systematically. Even the efforts of Alžbeta Güntherová Mayerová, who, like Assoc. Prof. Wagner, worked at the Povereníctvo školstva (Ministry of Education), were assessed as insufficient. ${ }^{50}$ The change was also reflected in the number of students. A new class would only be enrolled if there were at least ten students. Otherwise, the candidates would be advised to apply to the Charles University in Prague, which had a larger staff. With regards to staffing, Wagner proposed and the Department approved the Candidate of Science process for Marián Váross, an assistant at the Slovak Academy of Sciences, who had studied philosophy at the Sorbonne in Paris (1945-1947) and in Cambridge (1948-1949). Bakoš's proposal within the future development plan to hire Elena Šterbová and Radislav Matuštík was also approved.

The minutes from the Department of Art Sciences meeting from the end of June 1951 provide insight into the evaluation of the first working results in the new system. ${ }^{51}$ Prof. Bakoš stated that the decentralization of the Department into several sub-departments facilitated their progress, that the quality of the lectures had improved thanks to the regular criticism and self-criticism of educators' work, and that the ideological discussions contributed to clarifying a number of important issues. Thus, the organizational structure of the Department was supposed to remain unaltered. In the following year, theatre studies were to be transferred to the Academy of Performing Arts in Bratislava and the Department added Library Science. The session began with a presentation on the issues of Marxist - Leninist aesthetics in terms of Stalin's works (according to Trefin and Volkov) which was followed by a discussion and presentations by the sub-departments on the previous term. As for Art History, it was stated that there were some difficulties, including absences of the educators from Prague. Nevertheless, the target was met. The Sub-department met systematically and at each session an ideological problem was discussed and critiques and analyses of the work of individual lecturers were presented. Part-time pedagogues Volavka, Mencl and Kotalík did not attend the sessions. On the other hand, due to the small Sub-department team, Prof. Bakoš proposed that guests and external experts from the field be invited to enhance the discussions. The Sub-department aimed at closer cooperation with Zväz

${ }^{50}$ It was these two people who put into practice the Act No. 9864-1/5 issued by Minister of Education, Science and Art Ladislav Novomestský, owing to which the Monuments Board of the Slovak Republic was established in Bratislava on January 1st, 1951.

${ }^{51}$ RO FA CU BA, Fond A II/1, A5 Zápisnice zo zasadnutí Katedry vied o umení 19511959, Zápisnica z 26. júna 1951, particularly p. 1 and 4. 
slovenských výtvarných umelcov (the Alliance of Slovak Visual Artists). A surviving individual report of the Sub-department of Art History covering the spring/summer term of 1951 outlines certain outcomes. ${ }^{52}$ The nine bullet points in the three-page report inform us of the pedagogical process (lectures, seminars, their content and extent, the educators, the average grade from exams, and other points) and of ideological - political work. The ideological discussions that were requested covered the following subjects: On Base and Superstructure, Cosmopolitanism and Bourgeois Nationalism in Fine Art, The Tasks of Art History on the Road to Socialist Realism, the Marxist Method of Work, and the continuation of the discussion from the conference in Bechyně, Proletkultism in Our Art and the Tasks of Art Criticism.

In subquent years, the structure and operation of the department remained unaltered and there were attempts to restore and expand the book and slide collections of the Sub-department of Art History. According to the minutes of their sessions, we noted an interest in connecting education with practical internships. In 1953, this subject was elaborated on in Sub-department discourse on the article by Alpatov on the helplessness and lack of independence of art history graduates caused by a deficiency in the plans of study and the disconnect between theory and practice. ${ }^{53}$ In the pursuit to develop experts in art history, the Sub-department decided to abandon multi-subject syllabuses, merged some courses, accelerated the preparation of textbooks, introduced the requirement to write an annual thesis and narrowed the subjects of diploma theses. However, the new social-political conditions of the early 1950s had an ultimate effect on art history with regards to the teaching staff. Firstly, Jiři Kostka (ill. 5), a student of Antonín Matějček and an employee of the National Heritage Institute in Prague, was hired as a part-time lecturer. Along with recent graduate Elena Dubnická (Šterbová), the only politically engaged educator of art history, he was expected to create an ideological counterweight to the old generation, contaminated by their bourgeois education..$^{54}$ The social - political change had a particularly tragic impact on Alžbeta Güntherová Mayerová. In 1949, her husband was accused of collaborating with the US and killed during his interrogation by the State Security officers, and she consequently bore the stigma of his accusation. She became a target of denouncement leading to her forced resignation from the Faculty in 1952 and relocation from Bratislava as part of

52 RO FA CU BA, Fond A II/1, A5 Zápisnice zo zasadnutí Katedry vied o umení 19511959. Správa o činnosti subkatedry dejín výtvarného umenia za letný semester 1951.

${ }^{53}$ RO FA CU BA, Fond A II/1, A5 Zápisnice zo zasadnutí Katedry vied o umení 19511959, Zápisnica z 5. novembra 1953.

${ }^{54}$ Compare with Bakoš, "Príbeh zakliatej vednej disciplíny," p. 13; 95+ Dejiny umenia..., p. 12. 


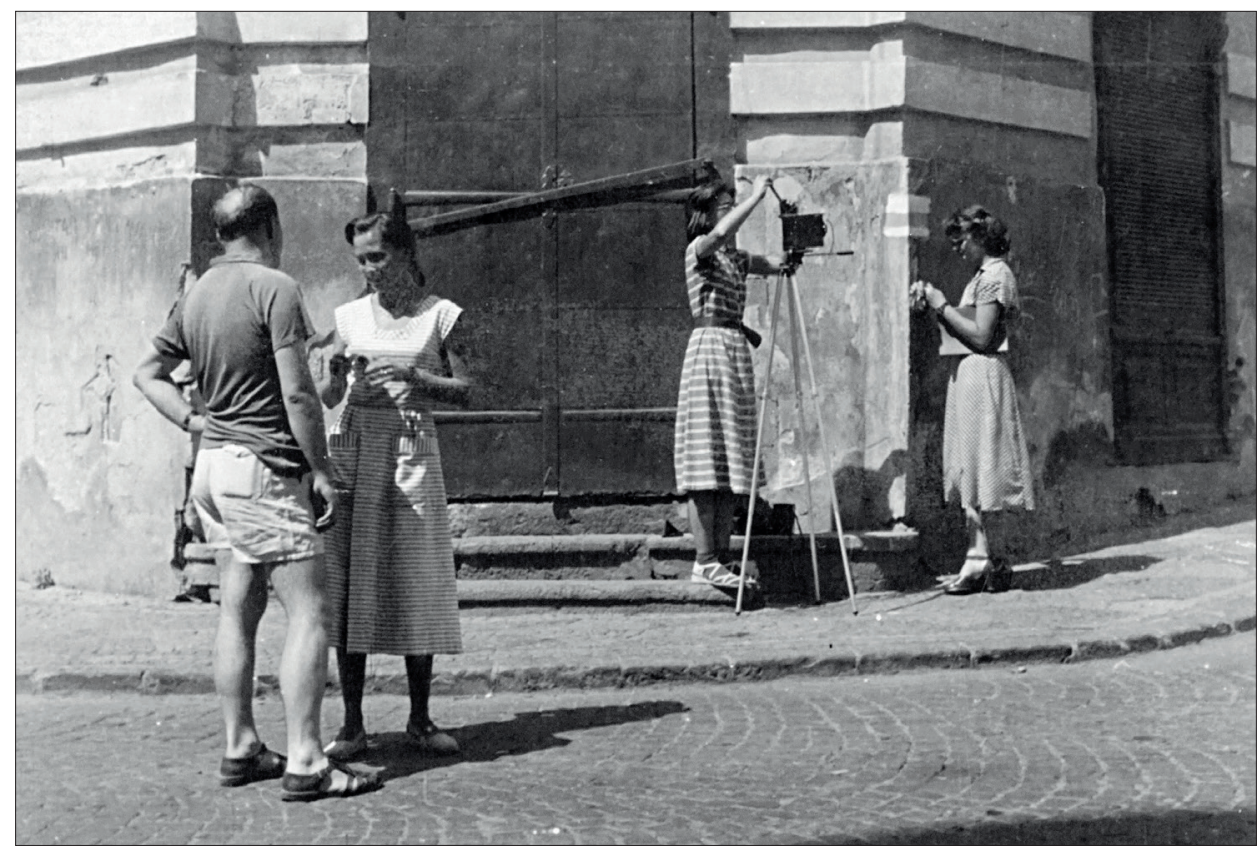

5. Jiří Kostka with art history students in Banská Štiavnica in the year 1955. Photo: ADAH FA CU BA

the Akcia B (Mission B) process conducted against fascists and later against bourgeois and politically unreliable elements. She was forced to move with her little son to Betliar, where she was hired to manage the Betliar manor house and Krásna Hôrka castle. ${ }^{55}$ Shortly after, Václav Mencl left the university in Bratislava due to ideological reasons, this time for good.

After the deaths of Stalin and Gottwald in 1953, the period of 'leftist sectarianism' came to an end, and Nikita Khrushchev proclaimed science to be an irreplaceable element in the building of communism. Therefore, science became another sphere of radical change. Unlike 1950, Soviet experts in Czechoslovakia encouraged a moderate attitude towards 'bourgeois experts' and criticized the anti-intellectualism of the Communist Party of Czechoslovakia. ${ }^{56}$ Intimidation was to be replaced by education towards Marxist philosophy. The Party

55 For more information, see J. Barczi, "Alžbeta Güntherová Mayerová (1905-1973). Život zasvätený pamiatkam," Monument revue 2013, 1, p. 23; idem, "Alžbeta Güntherová Mayerová - roky vyhnanstva 1952-1955," Monument revue 2013, 1, pp. 28-33.

${ }^{56}$ Hudek, "Sovietizácia pracovísk...," p. 349. Separate Ministry for Higher Education Institutions operated in Czechoslovakia in 1953 for 9 months. Gabzdilová, Ako sme študovali $v$ totalite, p. 39. 
resolution from 1953 dealing with the situation at universities restricted the authority of their own organizational bodies and returned it to the offices of deans and rectors, stating that the Party did not have the authority to control universities. Temporarily, there was room for dealing with the acute problems of the Faculty of Arts, such as the critical lack of qualified educators.

Concurrent with these changes, and shortly after Václav Mencl's forced resignation in 1953, the Sub-department of Art History in Bratislava realized the need to re-hire Güntherová Mayerová. Thus, this student of František Žákavec and Hans Tietze, only recently discharged from the University, no longer taught museological subjects but primarily art history courses from the very core of the field. She commuted all the way from Betliar, as the University was not her prime employer. ${ }^{57}$ The plan of study from 1954 (ill. 6) documents the change in the extent and significance of her involvement in the education of art history at the University of Bratislava. The plan was compulsory for the 5-year study of art history (extended from the previous 4-year programme) starting in the 1954/55 academic year. ${ }^{58}$ In 1954, when the university regained its original name, Comenius University, the Faculty of Arts failed in its attempt to award Güntherová Mayerová the title of associate professor. ${ }^{59}$ Nevertheless, that very same year she was appointed state associate professor at the Slovak University of Technology. However, the stigma of a politically undesirable person remained.

At that time, several notable changes related to art history at the university took place. The minutes of the entire Department of Art Sciences from November 1954 noted that Prof. Bakoš moved to split up the Department. According to the proposal, three independent departments were to emerge. ${ }^{60}$ One of them was to be the Department of Art History with Prof. Wagner as head. More detailed information was supposed to form an appendix to the minutes, but its whereabouts are unknown. Unfortunately, the motion was

57 In Betliar, she was employed by the Krajský národný výbor in Košice (District Administration Body). A letter to K. Kahoun from 9th June 1954, one of the hitherto unknown documents revealing the reality of coeval university activity, testifies to her typical fastidious attitude toward them as well as towards students. AFA SNG BA, Osobný fond A. Güntherová Mayerová, sign. 10 C 129.

${ }^{58}$ From the recorded subjects and educators, she had the largest contribution. In comparison with the plan of study of art history in Bratislava from the interwar and war period, we can observe systematization of the study and the increase in the number of subjects. 95+ Dejiny umenia..., p. 14, 97.

59 Šefčáková, "Alžbeta Güntherová Mayerová...," pp. 30-31.

${ }^{60}$ RO FA CU BA, Fond A II/1, A5 Zápisnice zo zasadnutí Katedry vied o umení 19511959, Zápisnica z 20. a 27. novembra 1954. 
UČEBNII PLÁN

studia déjin uměni
Vysoká Ykola: UNIVERSITY

Fakulta: FLLOSOFICKO-HISTORICKA (FILOSOFICKA) OznaZeni absolventa: PROMOVANÝ HISTORIK Delka studia: 10 SEMESTRÜ

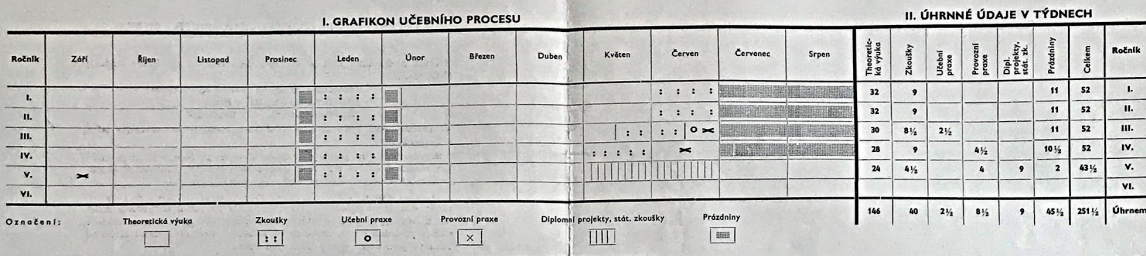

PLAN UČEQNIHO PROCESU

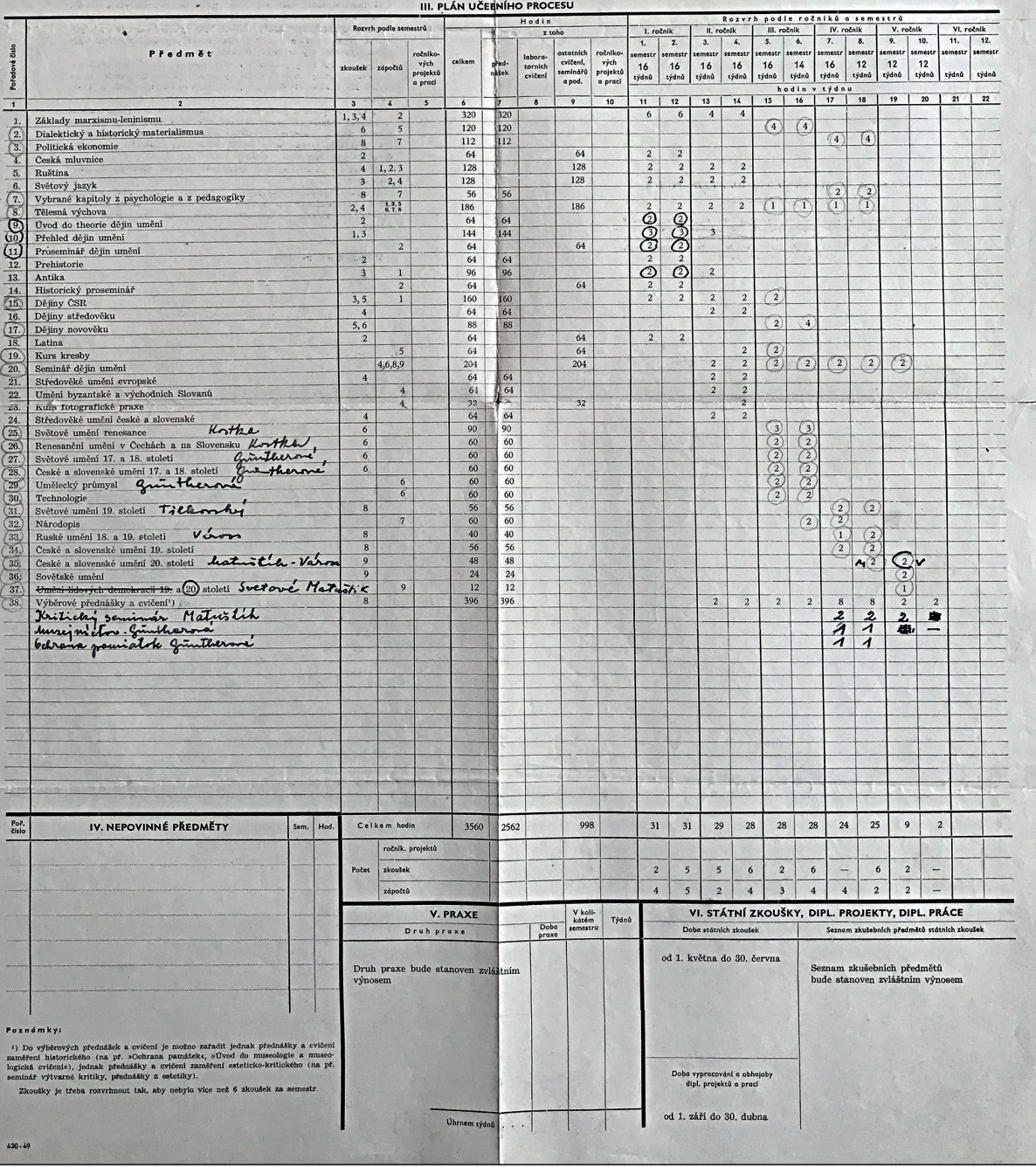

6. Plan of art history study at Comenius University in Bratislava for the academic year 1954/55. Photo: AFA SNG BA 
not passed. Nevertheless, the idea of art history gaining independence in the form of its establishment as a separate department continued to be circulated.

Moreover, in 1954 and 1955 there were substantial changes, both in terms of size and stability, in the organizational structure of the Sub-department of Art History. A new generation of important figures had arrived. Radislav Matuštík and Tomáš Štraus were originally appointed to the Sub-department of Aesthetics and after Wagner's departure in 1955, Karol Kahoun joined the staff. Matuštík and Štraus's teaching included art history subjects. ${ }^{61}$ From the staff of 1950 comprised of Vladimír Wagner, Václav Mencl, Jaroslav Dubnický and Alžbeta Güntherová Mayerová, only Güntherová Mayerová remained. During the two years of her resumed employment at Comenius University, she managed to prove herself, and after the sudden death of Prof. Wagner in 1955, she finally became a full-time employee at that university. This marked her last but most significant period there. From her official position of assistant, she was the de facto head of the Sub-department of Art History ${ }^{62}$ for the next six years. Nevertheless, the Sub-department, though officially only a field of study, was still part of the large Department of Art Sciences led by Prof. Bakoš. ${ }^{63}$ Naturally, at the time, the Marxist Theory of Art was the official teaching method. However, she introduced her students to the ideas of the Vienna School of Art History, particularly Tietze's version. ${ }^{64}$ One can learn much more about her pedagogical work at the University from her written self-criticism. ${ }^{65}$ Three pages of factual text with a clear structure testify to her remarkable ability to put into words, with a measure of detachment and without offending anyone, a poten-

${ }^{61}$ Compare with Bakoš, "Príbeh zakliatej vednej disciplíny," p. 13; 95+ Dejiny umenia..., pp. 12-14.

${ }^{62}$ The used title is in accordance with coeval use - Archív Katedry dejín umenia Filozofickej fakulty Univerzity Komenského v Bratislave / Archive of the Department of Art History Faculty of Arts Comenius University in Bratislava (ADAH FA CU BA), Plán práce odboru dejín umenia na šk. rok 1958/59, p. 2 "...zasadnutia odboru /quasi subkatedry/". There are also letters from the Academy of Fine Arts and Design rector office concerning the cover for Assoc. Prof. Volavka from January and February 1958, addressed to the Sub-department of Art History FA CU.

${ }^{63}$ Compare RO FACU BA, Fond A II/1, A5 Zápisnice zo zasadnutí Katedry vied o umení 1951-1959, 95+ Dejiny umenia..., p. 66.

${ }^{64}$ Bakoš, "Príbeh zakliatej vednej disciplíny," p. 13.

${ }^{65}$ AFA SNG BA, Osobný fond A. Güntherová Mayerová, sign. 10 E 322. Published in extenso without commentary and date see: A. Güntherová Mayerová, "Zhodnotenie vlastných prednášok z dejín umenia (rukopis, nedatovaný)," Monument revue 2013, 1, p. 34. K. Kolbiarz Chmelinová, "The pedagogical activity..." Due to the content of the self-criticism (otherwise not explicitly dated) related to the lectures commissioned by the Slovak University in 1953 and the mention of the self-criticism from the previous year, we may date it 1954 or possibly 1955. 
tially dangerous statement that was required in that time. She even managed to subtly educate the reader on the political role of official art using the example of Byzantine art, which she taught, while also cleverly cautioning readers against narrow-mindedness in assessing the complex phenomenon of art between the lines of the required call for its new propagandistic-popular form (ill. 7).

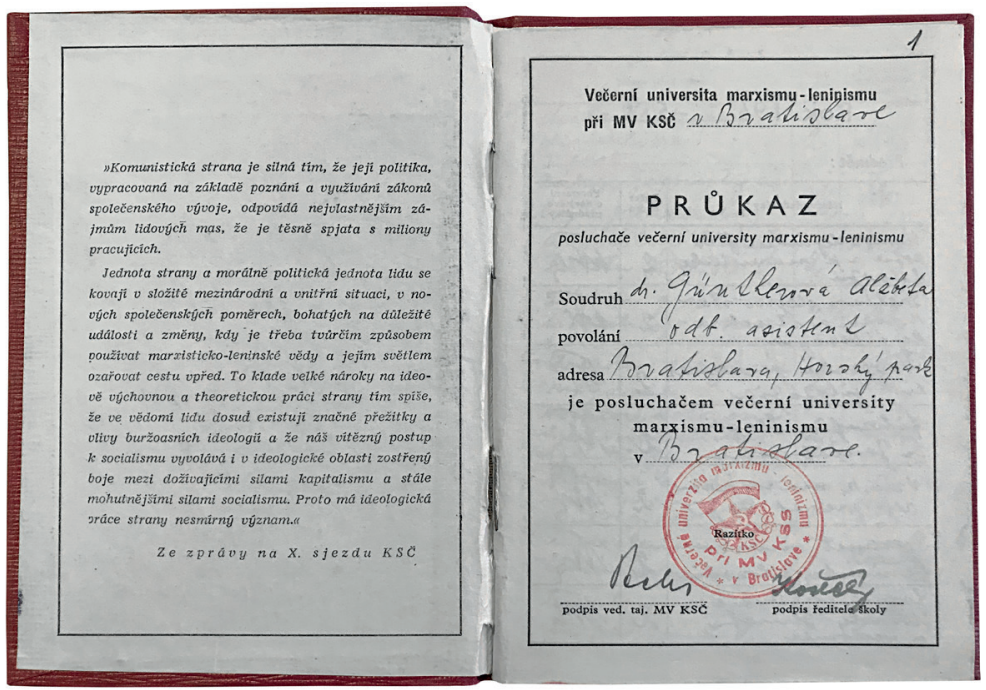

7A. Alžbeta Güntherová Mayerová's study card from Marxism Leninism's Evening University from the academic year 1958/59, AFA SNG BA

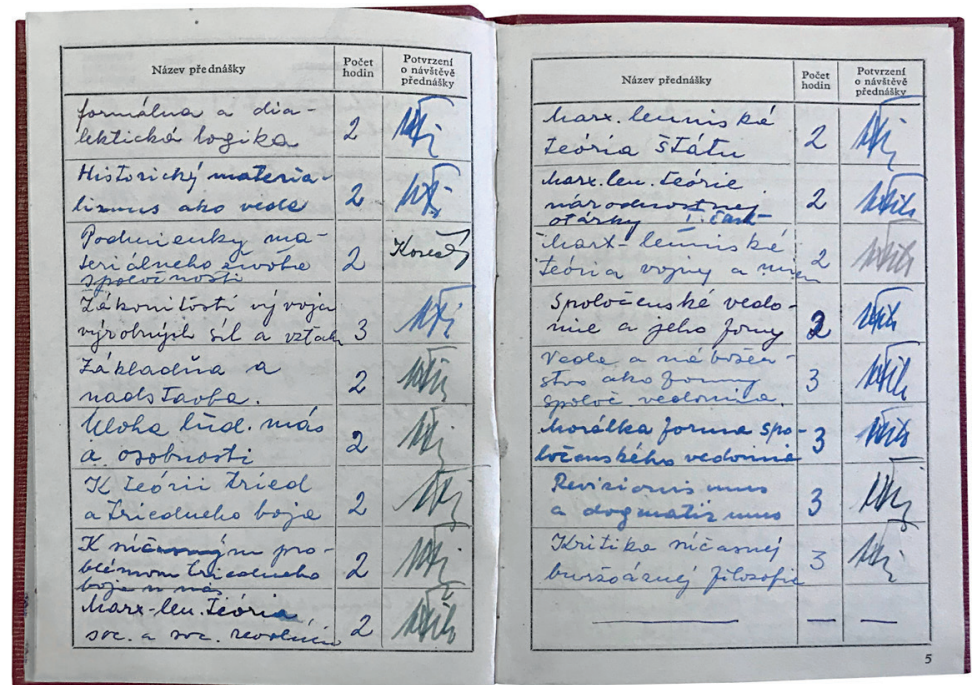

7B. Alžbeta Güntherová Mayerová's study card from Marxism Leninism's Evening University from the academic year 1958/59, AFA SNG BA 
It was Güntherová Mayerová who in June 1956, after an agreement with the Department of Theory and Art History of the Slovak Academy of Sciences, drafted and submitted a proposal to establish the Institute of Art History at the Faculty of Arts of Comenius University in Bratislava. ${ }^{66}$ This took place in September, before the new Higher Education Act 46/1956 came into effect, concerning institutes of a similar nature in Article 16. Its intention was to further strengthen centralisation and education in the spirit of communist ideas. ${ }^{67}$ The objective of the proposed institute was to manage the research, heuristic and documentary work from the field of art history in Slovakia based on a plan coordinated not only with the Slovak Academy of Sciences but also with the Monuments Board. The Institute was supposed to be affiliated to the Art History field of study at Comenius University. She argued that there was a lack of professional art-historical staff at the Academy of Sciences and that the pressure to work on tasks of art historical inventory, catalogue, dictionary and corpus character publications could be handled by the university staff, as well as its most talented students. Despite the fact that the objective was not met, the document proves the strengthening of the position of the Art History at the Faculty of Arts of Comenius University. Its self-reflection and successful establishment under the name sub-department or even department of art history, despite being officially merged with the Department of Art Sciences, also testifies to this fact. ${ }^{68}$ It might have been strategically interrelated with the activities concerning the preparation of a new network of universities and with the regulation of university operations, which the Department discussed during their meeting in December 1958. The later reorganization of art sciences in 1960 related to the need to finalize the cultural revolution might have also been part of the strategy. ${ }^{69}$

The minutes from the meeting of the Department of Art Sciences of October 1958 with the attached work plan for 1958-1959 (ill. 8) reveal further details. One of the tasks that arose from the Congress of the Communist Party in that year was the Department's organization of Saturday seminars on art criticism featuring lectures on art history by Dr. Marián Váross, an external

66 AFA SNG BA, Osobný fond A. Güntherová Mayerová, sign. 10 K 621.

67 <https://www.slov-lex.sk/pravne-predpisy/SK/ZZ/1956/46/vyhlasene_znenie. html $>$ [accessed: 31.5.2019].

${ }^{68}$ E.G. in 1958 the sub-department of art history was consistently cited, and an official letter about the student F. Kriška was sent by the dean's office to the "Department of Art History". ADAH FA CU BA, List o prerušení štúdia F. Krišku z 1.3.1958.

69 ADAH FA CU BA, Zápisnica zo zasadnutia Katedry vied o umení z 13.12.1958, Návrh subkatedry dejín umenia k prestavbe umenovedných smerov 14.2.1960 and 14.12.1960, Prestavba výučby a výchovy na filozofických fakultách 27.10.1960. 


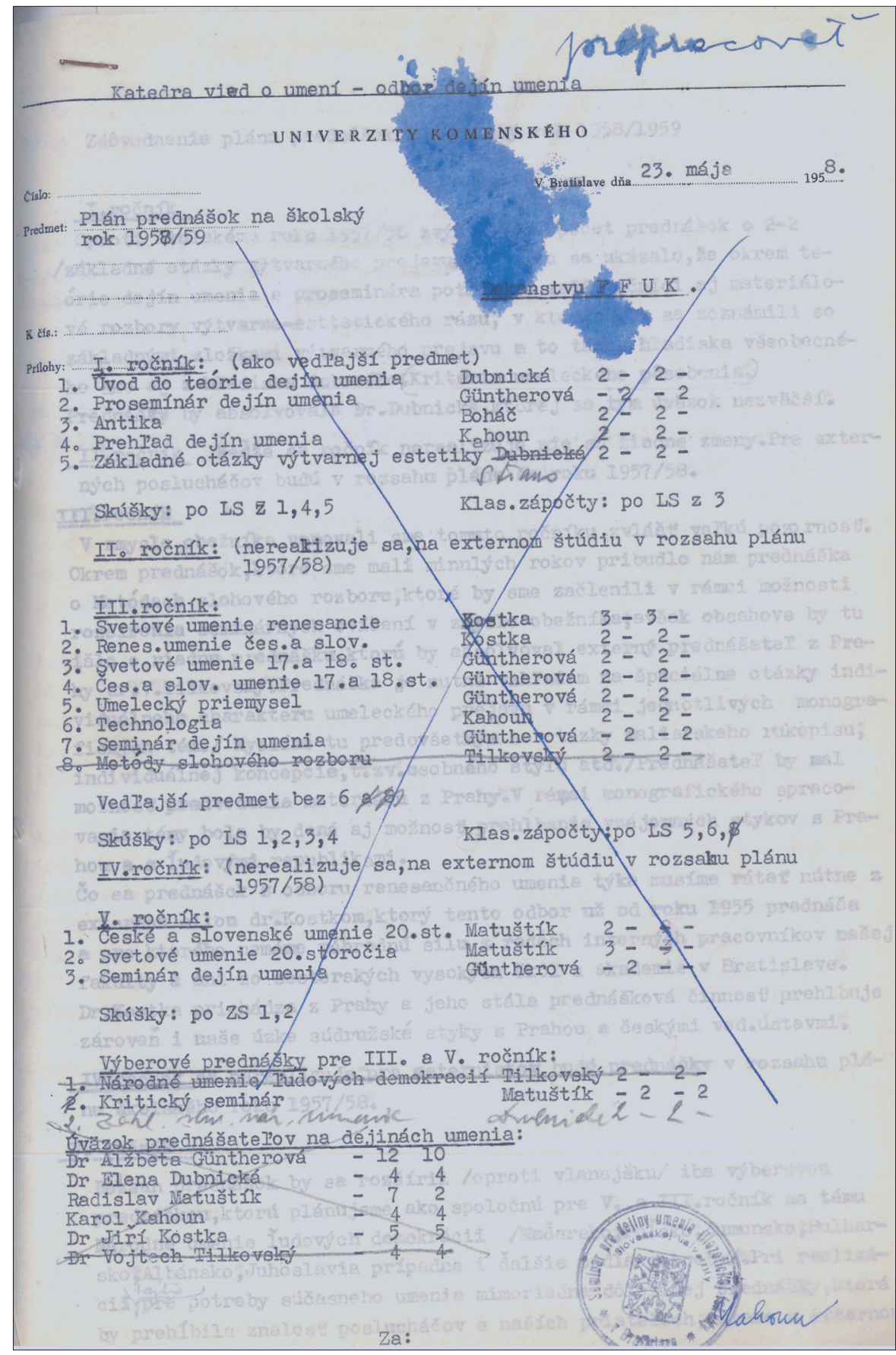

8. Plan of art history lectures at Comenius University in Bratislava for the academic year 1958/59. Photo: ADAH FA CU BA 
university teacher from the Slovak Academy of Sciences. ${ }^{70}$ The plan of the Sub-department of Art History clearly defines two developing branches of the field: a historical one and an aesthetic-critical one, which was especially represented by the work of Štrauss and Matuštík. Needless to say, the political-educational part came first and included mandatory participation in training sessions, and in the case of acting Assoc. Prof. Güntherova Mayerova, attending the Evening University of Marxism-Leninism. In addition to memberships, publication and research activities of the members of the department, the substantial part of the plan concerns pedagogical work and its improvement and methods to intensify the contact with practice. For this purpose, the plan emphasized the necessity to organize several field trips a year and called for the introduction of a photography course. ${ }^{71}$

However, this was happening in a fast-changing atmosphere, because the calm situation favoring professional development did not last long. As a consequence of the crisis linked to the Hungarian Revolution of 1956, the working-class intellectuals in Czechoslovakia were no longer considered supporters of the regime. Once again, stricter background reviews and screening activities were conducted, even among members of the Party, and "unreliable people were dismissed. At Comenius University it started in 1957 as a struggle against the remaining members of Hlinka's Slovak People's Party and bourgeois ideologues and others who, up to then, had been able to hold their posts because of their expertise. ${ }^{72}$ In the following year, although it was a period of dismissals, Art History managed to retain all of its members. This must also have been due to the fact that it was forced to accommodate some of the students from the abolished Pedagogical University. Unfortunately, the situation changed dramatically and it soon claimed its victims (ill. 9).

Art History, under the leadership of Güntherova Mayerova, continued fighting for its position. In the proposed plan of work and consequently in the activity report for 1959/60, one can discern increased interest in the ideological-political education of pedagogues themselves, and through them the students. They stimulated pedagogues politically by means of various as-

${ }^{70}$ ADAH FA CU BA, Zápisnica zo zasadnutia Katedry vied o umení z 20.10.1958 a plán práce na rok 1958/1959. Meetings took place on Saturdays at 10am at 12 Šafárikovo Sq. (October $25^{\text {th }}$, November $8^{\text {th }}$ and $22^{\text {th }}$, December $6^{\text {th }}$ and $\left.20^{\text {th }}, 1958\right)$.

${ }^{71}$ In that year field trips were scheduled in South Bohemia and Prague. Dresden remained only at the planning stage. ADAH FA CU BA, Plán práce odboru dejín umenia pre akademický rok 1958/1959, the plan is not dated and bears no signature.

${ }^{72}$ Hudek, "Sovietizácia pracovísk...," pp. 350-351. P. Cajthaml, M. Ďurčanský, "Dobové souvislosti a ohlas prověrek politické trííní spolehlivosti v roce 1958 na Univerzitě Karlově," in: Práce z dějin Akadémie věd, vol. 2, pp. 118-130. 


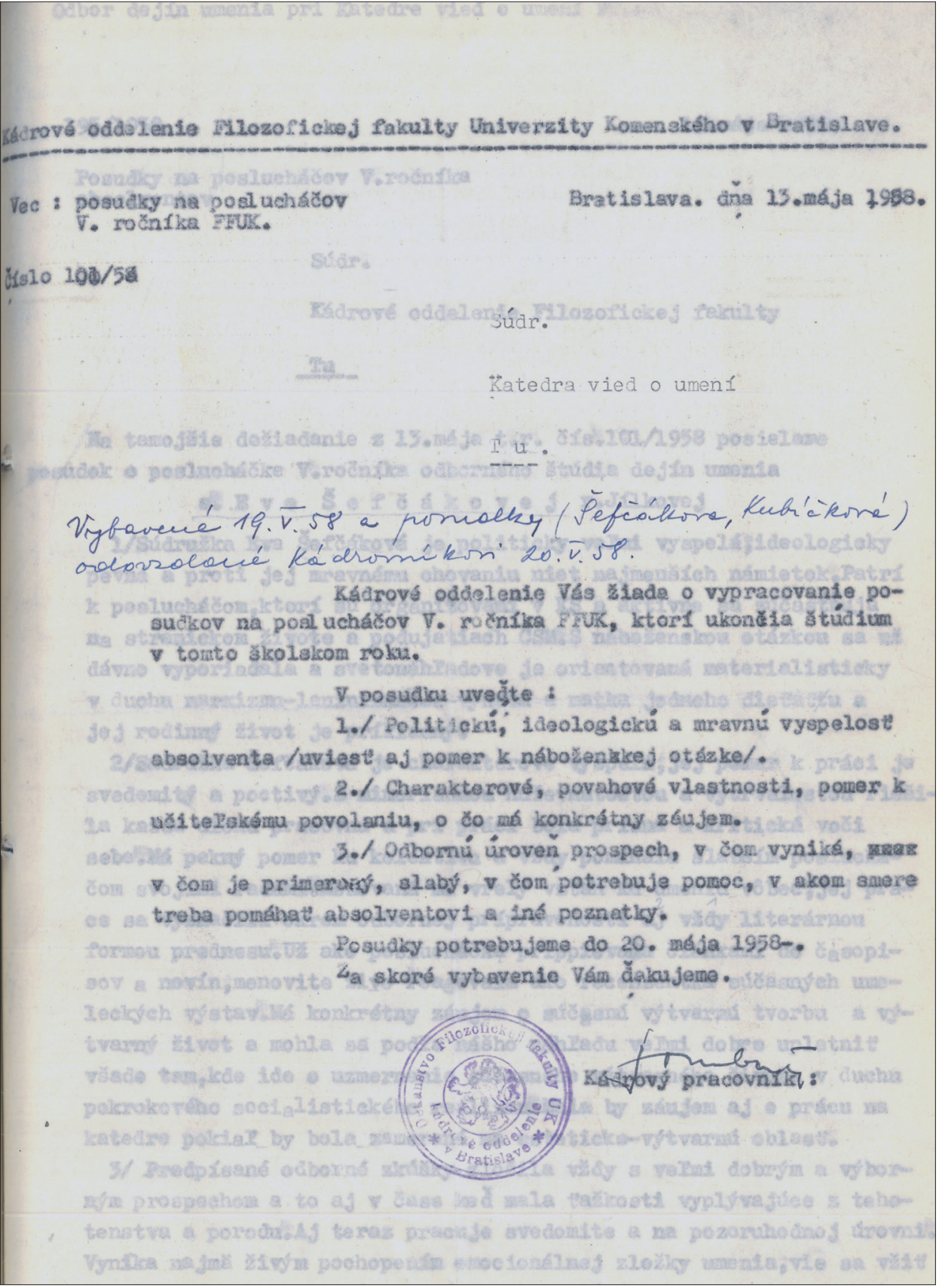

9. Request to send cadre assessments of art history students at Comenius University in Bratislava, 1958. Photo: ADAH FA CU BA 
signments and appointments. In addition to the requirement that Güntherova Mayerova attend the Marxism-Leninism Evening University, Matuštík, Štraus and Kahoun had to complete a two-year philosophical-aesthetical course at the same university. Pedagogues also attended lectures on atheism. The lecturers dealt with questions related to the finalizing of the cultural revolution and actively contributed to meetings with the working class on the preparations of the Congress of Socialistic Culture. Shortcomings were observed in the inadequate ideological-political influence on students, which was to be improved. Nevertheless, the actual pedagogical activities and even publication and scientific research activities were assessed on the same scale. The assessment also included monitoring activities outside the Faculty.

In 1960, the Sub-department of Art History acted competently as part of the Department of Archeology, Art History, Ethnology and Folklore Studies. Since the closure of the Department of Art Sciences, it also became responsible for all remaining students studying Visual Arts Education at the Pedagogical University. Art History was available for full-time and part-time students. Speaking on behalf of the Sub-department, Güntherová Mayerová requested permission to conduct research (not only within individual plans but also in departmental plans) and to set up an autonomous workplace for research, ideally for the sole use of the Art History Sub-department or for the whole Department of Archeology, Art History, Ethnology and Folklore Studies. ${ }^{73}$ In the same year, the Sub-department, under the supervision of Güntherova Mayerova, undertook the arduous task of relocating to the third floor of the building on 2 Gondova Street, where it has remained until now. Up until October of that year, she worked in the capacity of acting associate professor. and Deputy Head of the Department, and also dealt with issues concerning part-time students. Other people working in the Sub-department included Dubnická, Kahoun (ill. 10), Matuštík, Štrauss and adjunct educators Kostka and Váross (three hours per week on Czechoslovak Modern Art) and the archeologist Novotný. Her pedagogical work still focused on art history with 14 hours of lectures and 7 hours of consultations per week. Some of her lectures have been preserved in her manuscripts. ${ }^{74}$ Güntherová Mayerová managed to prepare a development plan for research for this department up to 1970, as well as a new syllabus of subjects and other requisites necessary for the next transformation of university studies. ${ }^{75}$

73 ADAH FA CU BA, Vyjadrenie k obežníku dekanátu FiF UK zo 14.12.1960.

${ }^{74}$ AFA SNG BA, Osobný fond A. Güntherová Mayerová.

75 ADAH FA CU BA, Výhl'adový plán vedy a výskumu do roku 1970 vypracovaný v roku 1958 a nové osnovy predmetov z 25.12.1960. 


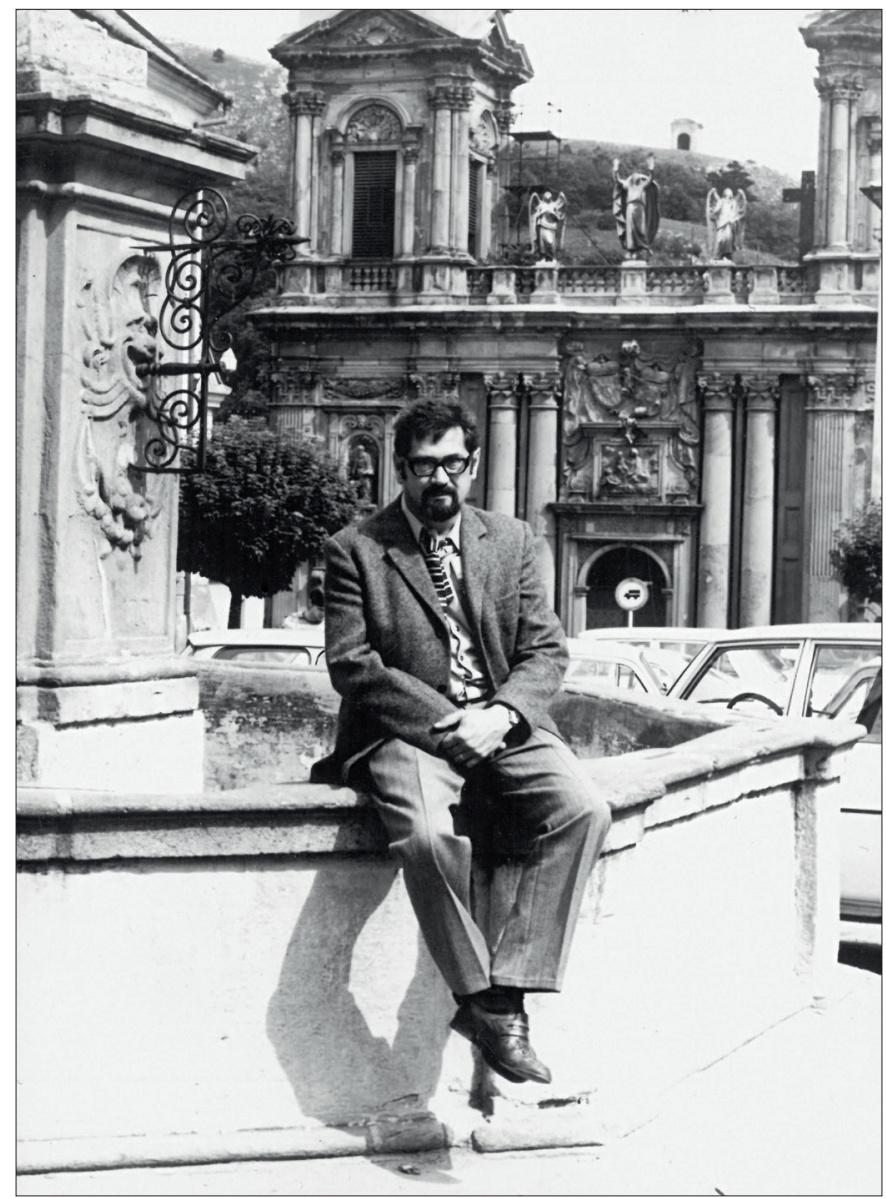

10. Karol Kahoun in Mikulov in the late 1960s / early 1970s. Photo: ADAH FA CU BA

Unfortunately, the resurgence of political pressure did not only result in the constant postponing of Güntherova Mayerova's appointment as professor. The following year - 1961-was her last at Comenius University. She was once again judged to be politically unreliable and dismissed. In doing so, the university disposed of an exceptionally admirable art history expert and replaced her with someone from the Education Department of the Slovak National Council, who was only qualified to work in a library and handle the department's administrative issues. ${ }^{76}$ Once again, the Art History Sub-department faced staffing issues and was operating under provisional arrangements. Worse still,

${ }^{76}$ ROFA CU BA, Fond A II/1, A5 Zápisnice zo zasadnutí Katedryvied o umení, Zápisnice zo zasadnutí Katedry archeológie, dejín umenia, etnografiky a folkloristiky, Zápisnica z 29.9.1961. 
from the point of view of the quality and direction of instruction, this was the beginning of the long-lasting career of Pavol Michalides, a Party member without adequate art history erudition. ${ }^{77}$ Güntherová Mayerová left the university with poor references and attempted to gain employment in Prague. ${ }^{78}$ Ultimately, she was assigned to the Monuments Board of the Slovak Republic, which marked the beginning of another important chapter of her life's work and the formation of the well-known list of monuments which she edited. ${ }^{79}$ At that time, after Comenius University had been thoroughly Sovietized in every respect, from its organizational structure and staffing, to its ideology, several years of relatively tranquil progress followed..$^{80}$

As it arises from this account, in the postwar years 1945-1948 we can observe a transition in Slovakia from one dictatorship to another; the domination of the school system and its centralization was also part of the new political struggle for power. Ideas related to the independent management of the school system in Slovakia in re-established Czechoslovakia ceased to exist after the Prague Agreements in 1946, and after Victorious February 1948, and schools at all levels began to be managed centrally by the Communist Party with the intent to transform them according to the Soviet model. With respect to different developments in the course of WWII, the transformations in Slovakia were different to those in the Czech Republic (earlier nationalization, different background of human resources, smaller impact of the first political purges ...). Meanwhile, the Bratislava Art History Seminar fought throughout with provisional efforts to maintain its own existence.

The system changes in university teaching of art history in Slovakia began with the passing of the new Act on Higher Education Institutions in 1950. The transformation that took place at the beginning of the turbulent decade of the 1950s had two sides. First of all, it brought along centralization and the dominant ideological control of the Communist Party of Czechoslovakia which, since the fall of the socialist era, was behind the overall condemnation of the entire period. This was manifested in the loss of independence, an essential element in academia, by the vetting of personnel and purges, as well as the permanent control of ideological instruction and the involvement of students and teachers. Various tools were used for this purpose, starting with

77 His lectures were regarded as incompetent, perhaps comical, by students. $95+$ Dejiny umenia..., pp. 52-53, 67. See also P. Michalides a kol., Palo z múru - hybský rodák, Bratislava 1996.

78 Šefčáková, "Alžbeta Güntherová Mayerová...," p. 32.

79 Súpis pamiatok na Slovensku, vol. 1-3, ed. A. Güntherová Mayerová, Bratislava 1967-1969.

${ }^{80}$ Hudek, "Sovietizácia pracovísk...," p. 351. 
the establishment of a separate Department of Marxism-Leninism and compulsory university courses for students, through various forms of controlled ideological education of teachers, such as Večerná univerzita Marxizmu-Leninizmu (Evening University of Marxism-Leninism), up to targeted ideological papers and discussions at the beginning of department meetings.

On the other hand, there was an obvious effort to unify and professionalize the teaching of our discipline, but not only ours, in Czechoslovakia, and to a certain extent, we are the heirs of this effort. In addition to others, this is proven by the aforementioned new, and for the first time, comprehensive study plans and curricula, which, despite their political burden, stand in sharp contrast to the insignificant number and composition of art history courses at the university before and during the war by virtue of their number of hours and the orientation of their content. Furthermore, in compliance with the ideas at that time regarding the primary pedagogical orientation of universities and the transfer of research to academies of science, the archive materials show a politically motivated but still unusually high interest in didactics. The burden on teachers comprising various related tasks grew considerably (complying with the plan of tasks, the pressure to create study materials, course books, increased hours of consultation and controls of study activities....). Complying with the new obligations accompanied by the system of their control proved to be a balancing act on the edge of formality and potential danger. Regular discussions on topical forms and the possibilities of pedagogical activity were part of it, which reached the level of individual departments in the personalized form of publicly controlled criticism and degrading self-criticism of individual teachers.

The former Seminar of Art History at the University of Bratislava was no exception. It lost most of its independence in the new structure of the faculty. After implementing the conclusions of the $9^{\text {th }}$ Congress of the Communist Party of Czechoslovakia and the Communist Party of Slovakia and the regulations of the new Act on Higher Education Institutions in 1950, the new form of instruction provided by this Seminar was marked by the compulsory introduction of Marxism-Leninism in 1951-52. Due to the application of repressive Party measures, a resolute change in the composition of teachers of art history occurred in the following years of 1953-1955.

Numerous structural, content and staffing changes implemented swiftly one after another, the aim of which was to educate a politically advanced intelligentsia, were replaced by a brief lull in the middle of the decade. In connection with a certain liberalization following Stalin's death, this was made possible by a change in the attitude of the Czechoslovak government, which mitigated the influence of the Party in universities and showed a more benevolent approach, for some time, toward bourgeois experts. Moreover, the key transformations were introduced and the staffing of the Sub-department 
of Art History at Comenius University in Bratislava was temporarily stabilized. This allowed for the considerable development of this specialization in the second half of the 1950s. The proof of the strengthening of its position at the faculty was, in addition to other effects, in the form of its ambitions, which materialized in repeated proposals to establish a scientific institute of art history at the university. These were at variance with the efforts at that time to transfer science to the academies. However, the situation began to deteriorate relatively early, and due to negative social and political changes, another wave of political and professional purges followed after 1957. They did not directly affect the Sub-department of Art History at Comenius University at first, which was probably due to the broadening of its competences and the lack of an expert staff. However, this did not last long and Alžbeta Güntherová Mayerová, the leading figure of the discipline, became a victim of the aforementioned situation. Her forced resignation in 1961, along with the disintegration of the synthetic Department of Art Sciences covering the discipline, opened a new chapter in university art history in Bratislava.

\section{BIBLIOGRAPHY}

Archív Katedry dejín umenia Filozofickej fakulty Univerzity Komenského v Bratislave / Archive of the Department of Art History Faculty of Arts Comenius University in Bratislava (ADAH FA CU BA)

- List o prerušení štúdia F. Krišku z 1.3.1958

- Návrh subkatedry dejín umenia k prestavbe umenovedných smerov 14.2. a 14.12 .1960

- Prestavba výučby a výchovy na filozofických fakultách 27.10.1960

- Plán práce odboru dejín umenia na akademický rok 1958/59

- Vyjadrenie k obežníku dekanátu FiF UK zo 14.12.1960

- Výhl'adový plán vedy a výskumu do roku 1970 vypracovaný v roku 1958 a nové osnovy predmetov z 25.12.1960

- Zápisnica zo zasadnutia Katedry vied o umení z 13.12.1958

- Zápisnica zo zasadnutia Katedry vied o umení z 20.10.1958

Archív Univerzity Komenského v Bratislave / Archive of the Comenius University in Bratislava (A CU BA)

- Fond: Zápisnice zo zasadnutia Akademického senátu 1949-1950

Archív výtvarného umenia Slovenskej národnej galérie v Bratislave / Archive of Visual

Art of the Slovak National Gallery in Bratislava (AFA SNG BA)

- Osobný fond A. Güntherová-Mayerová, sign. 10 E 342

- Osobný fond A. Güntherová Mayerová, sign. 10 C 129

Registratúrne stredisko Filozofickej fakulty Univerzity Komenského v Bratislave / Registrar office of the Faculty of Arts Comenius University in Bratislava (RO FA CU BA),

- Slovenská univerzita v Bratislave, Soznam osôb, ústavov a štátnych skúšobných komisií podl'a stavu na začiatku študijného roku 1944/45 
- Slovenská univerzita v Bratislave, Soznam prednášok, ktoré budú v zimnom semestri študijného roku 1944/45

- Fond A II/1, A5 Zápisnice zo zasadnutí Katedry vied o umení 1951-1959

- Zápisnice zo zasadnutí Katedry archeológie, dejín umenia, etnografiky a folkloristiky 1961

95+ Dejiny umenia na Univerzite Komenského v Bratislave, eds. K. Kolbiarz Chmelinová, K. Beňová, Bratislava 2018

Bakoš J., Situácia dejepisu umenia na Slovensku, Bratislava 1984

Bakoš J., "Český dejepis umenia a Slovensko," Umění: časopis Ústavu dějin umění Akademie věd České republiky 1986, 3, pp. 211-228

Bakoš J., "Príbeh zakliatej vednej disciplíny. Seminár dejín umenia na Bratislavskej univerzite," in: Pocta Václavovi Menclovi. Zborník štúdií k otázkam interpretácie stredoeurópskeho umenia, Bratislava 2000, pp. 9-18

Barczi J., "Alžbeta Güntherová Mayerová (1905-1973)," Monument revue 2013, 1, pp. $20-25$

Barczi J., "Alžbeta Güntherová Mayerová - roky vyhnanstva 1952-1955," Monument revue 2013,1 , pp. 28-33

Cajthaml P., M. Ďurčanský, "Dobové souvislosti a ohlas prověrek politické třídní spolehlivosti v roce 1958 na Univerzitě Karlově, " in: Práce z dějin Akadémie věd, vol. 2, pp. 118-130

Ciulisová I., Dejepis umenia na Slovensku. Vybrané kapitoly, Bratislava 2011

Connelly J., Captive University: The Sovietization of East German, Czech, and Polish Higher Education, 1945-1956, The University of North Carolina Press, 2000

Gabzdilová S., Ako sme študovali v totalite. Vysokoškolské vzdelávanie na Slovensku pod ideologickým diktátom Komunistickej strany Československa 1948-1953, Prešov 2018

Güntherová Mayerová A., "Zhodnotenie vlastných prednášok z dejín umenia (rukopis, nedatovaný)," Monument revue 2013, 1, p. 34

Hudek A., "Personálna politika na historických katedrách Univerzity Komenského," in: idem, Najpolitickejšia veda. Slovenská historiografia v rokoch 1948-1968, Bratislava 2010, pp. 105-110

Hudek A., "Sovietizácia pracovísk historickej vedy na Univerzite Komenského v 50. rokoch, " in: 95 rokov Filozofickej fakulty UK, Pohlad do dejín inštitúcie a jej akademickej obce, eds. M. Slobodník, M. Glossová, Bratislava 2017, pp. 338-354

Hübner P., Nauka polska po II wojnie światowej. Idee I Instytucje, Warszawa 1987

Hübner P., Polityka naukowa v Polsce w latach 1944-1953. Geneza systemu, vol. 1, Wrocław-Warszawa-Kraków 1992

Jareš J., „Indiferentní - možnost převýchovy!“ Cíle tzv. studijní prověrky na vysokých školách a jejich realizace, in: M. Černá, J. Cuhra a kol., Prověrky a jejich místo v komunistickém vládnutí. Československo 1948-1989, Praha 2012, pp. 20-53

Koklesová B., "Seminár dejín umenia v rokoch 1939-1945," in: 95 rokov Filozofickej fakulty UK, Pohlad do dejín inštitúcie a jej akademickej obce, eds. M. Slobodník, M. Glossová, Bratislava 2017, pp. 306-322

Kotkin S., Magnetic Mountain: Stalinism as a Civilization, Berkeley-Los AngelesLondon 1997 
Kusá A., Prerušená pieseň. Výtvarné umenie v časoch stalinskej kultúrnej praxe 1948-1956, Bratislava 2019

Michalides P. a kol., Palo z múru - hybský rodák, Bratislava 1996

Okál J., Dr. Jozef Cincík. Pútnik dvoch svetov, Ontario 1980

Peterajová L'., "Pôsobenie Alžbety Güntherovej-Mayerovej na Vysokej škole výtvarných umení," in: Stretnutie so životom a dielom Alžbety Güntherovej-Mayerovej (1905-1973). Zborník príspevkov z kolokvia Umelecko historickej spoločnosti Slovenska 27.11.2003, ed. M. Herucová, Bratislava 2003, pp. 99-101

Pocta Karolovi Kahounovi. Súvislosti slovenského umenia: jubilejný zborník. 3, ed. Š. Oriško, Bratislava 2006

Pocta Václavovi Menclovi. Zborník štúdií k otázkam interpretácie stredoeurópskeho umenia, eds. D. Bořutová, Š. Oriško, Bratislava 2000

Pocta Vladimírovi Wagnerovi. Zborník štúdií k otázkam interpretácie stredoevropského umenia 2, ed. Š. Oriško, Bratislava 2004

Pšenák J., Pramene k dejinám Československého školstva (od. r. 1918-1973), Bratislava 1977 , pp. 11-17, 57-91

Šefčáková E., "Alžbeta Güntherová-Mayerová - život a dielo," in: Stretnutie so životom a dielom Alžbety Güntherovej-Mayerovej (1905-1973). Zborník príspevkov z kolokvia Umelecko historickej spoločnosti Slovenska 27.11.2003, ed. M. Herucová, Bratislava 2003, pp. 13-37

Stretnutie so životom a dielom Alžbety Güntherovej-Mayerovej (1905-1973). Zborník príspevkov z kolokvia Umelecko historickej spoločnosti Slovenska 27.11.2003, ed. M. Herucová, Bratislava 2003

Súpis pamiatok na Slovensku, vol. 1-3, ed. A. Güntherová Mayerová, Bratislava 19671969

Život a dielo P. Valéra Aurela Zavarského SJ: konferencia pri príležitosti nedožitých stých narodenín, Bratislava 23. septembra 2005, eds. L’. Csontos, A. Piatrová, Trnava 2005

https://www.slov-lex.sk/pravne-predpisy/SK/ZZ/1950/58/19660501 (15.5.2018)

https://www.slov-lex.sk/pravne-predpisy/SK/ZZ/1956/46/vyhlasene_znenie.html (31.5.2019)

Katarína Kolbiarz Chmelinová

Comenius University, Bratislava

UNIVERSITY ART HISTORY IN SLOVAKIA AFTER WWII AND ITS SOVIETIZATION IN THE 1950S.

\section{Summary}

In post-WWII Slovakia, art history was available only as a university field of study at Bratislava University (in 1954 regaining its name Comenius University) at the Seminár pre dejiny umenia / Seminar of Art History, a separate part of the Faculty of Arts of the university, where art history had been taught as an independent discipline since 1923 before its conversion to a department. 
Post-war changes in state structures and the new political system radically affected Slovak society and the education system in the country. This article is the very first attempt to present in detail the extent and character of changes in university art history instruction in the part of the socialist era of the Czechoslovak Republic. It is based on the study and comparison of previously unprocessed sources from various university and state archives and their classification in the context of known historical facts. This contribution represents an in-depth probe into the post-war efforts to build a new university foundation and system of art history instruction in Slovakia within the Czechoslovak Republic, and its Sovietization as well.

The text analyzes the university environment, the curriculum, the study program of art history and the relevant changes resulting from political pressure from 1945 to 1960. They were the consequence of two directly related, significant moments in the history of Slovakia: the establishment of the Third Czechoslovak Republic in 1945 and the communist coup in 1948, which was followed by the most totalitarian period in the history of the state. The article also discusses the personal changes in the art history staff forced by the political situation (J. Dubnický, V. Wagner, V. Mencl, A. Güntherová-Mayerová, R. Matuštík, T. Štrauss, K. Kahoun).

After a brief presentation of the situation in Czechoslovakia at the time, the article first deals with the ad hoc activities and efforts of scientists seeking to maintain art history studies in Slovakia at the university level immediately after the end of the war. The central issue in the article is the changes in the way of teaching resulting from the political upheaval in February 1948. Against the background of political and social changes, the new law on higher education (Act No. 58/1950), which forces significant organizational transformations, is discussed. As part of the process of Sovietization of university education in Slovakia, the modified Seminar of Art History lost its independent status for a long time, and its staff was largely replaced. At the same time, throughout this period, there was a visible tendency to stabilize the teaching system and attempts to become independent again and to develop discipline, undertaken contrary to the imposed system. The 1950s, with their new rhetoric and propaganda optimism, appear to be a decade devoid of internal consistency. It started the most totalitarian period, which lasted until Stalin's death in 1953, but was followed by a short thaw and then by a new wave of repression after 1957, which chose victims even at the beginning of the next decade. The article focuses on two sides of the 1950s - centralization and the dominant ideological control of the Communist Party, on one hand, and on the other, the obvious effort to unify and professionalize the teaching of the discipline.

The factual material presented here shows the scale of changes interpreted in the context of the political and social changes of that time. The case study provides an analysis of system efforts made in the 1940s and 1950s to establish new principles of university teaching for the history of art in Slovakia as part of the Czechoslovak Republic. It aims to broaden the factual basis and existing overview of knowledge of art history in Slovakia and supplement existing studies on the history of art history in the country (J. Bakoš, I. Ciulisová, B. Koklesová).

Keywords:

Art history, Slovakia, Comenius University in Bratislava, World War II, 1950s, Sovietization 